Acta Universitatis Wratislaviensis No 3799

PRAWO CCCXXIV

Wrocław 2017

DOI: $10.19195 / 0524-4544.324 .1$

\author{
ALEKSANDRA SZYMAŃSKA \\ Uniwersytet Wrocławski \\ aleksandra.kaczmarczyk@uwr.edu.pl
}

\title{
Dwanaście kolumn z Gortyny - historia odkrycia
}

Kreta obfituje w epigraficzne źródła poznania prawa. Obywatele kreteńskich poleis, takich jak Axos, Dreros, Eleutherna, Eltynia, Gortyna, Knossos, Lyktos czy Fajstos, umieszczali swoje prawa na ścianach budynków publicznych ${ }^{1}$. Wyryty na kamiennych tablicach tekst prawa był wystawiany do publicznej wiadomości. W Dreros prawa zostały spisane m.in. na ścianach świątyni Apollina Delfiniosa, w Gortynie zaś odnaleziono inskrypcje pochodzące ze ścian świątyni Apollina Pythiosa $^{2}$. W Gortynie znajduje się również najbardziej znany kreteński pomnik prawa - tzw. Kodeks z Gortyny. Ponieważ ta wielka inskrypcja odkryta pod koniec XIX w. na miejscu antycznego miasta, Gortyny, wciąż rozpala wyobraźnię historyków prawa, filologów, epigrafików i archeologów, warto poznać historię jej odkrycia.

Odkrycie Kodeksu z Gortyny miało miejsce w drugiej połowie XIX w. i wiąże się z aktywnością francuskich, a później włoskich archeologów na wyspie Minosa. W tym czasie Kreta była częścią imperium osmańskiego ${ }^{3}$. Działalność naukowa była wówczas utrudniona z uwagi na niepokoje społeczne i bunty przeciwko władzy tureckiej. Niemniej jednak realizacja francuskiego projektu, zmierzającego do przebadania wyspy, powiodła się dzięki charakterom i osobowościom

${ }^{1}$ Nie zawsze jednak udało się ustalić funkcję, czy nawet lokalizację tych budynków. Zob. P.J. Perlman, Writing on the Walls. The Architectural Context of Archaic Cretan Laws, [w:] Crete beyond the Palaces: Proceedings of the Crete 2000 Conference, red. L. Preston Day, M.S. Mook, J.D. Muhly, Philadelphia 2004, s. 182.

2 Ibidem, s. 195.

${ }^{3} \mathrm{~W}$ roku 1898 wyspa uzyskała autonomię pod nadzorem mocarstw europejskich. Została wówczas podzielona na cztery strefy wpływów. Region Chania został przydzielony Włochom, Rethymnon przypadł Rosji, Heraklion Anglii, region Sitia miała zaś nadzorować Francja. Dopiero w 1913 r., po wojnach bałkańskich, wyspę przyłączono do Grecji. 
zarówno osób kierujących przedsięwzięciem, jak i członków ekspedycji, a także dzięki ich stosunkom z lokalnymi władzami ${ }^{4}$ i miejscową ludnością, która służyła pomocą i wskazówkami. Niemałą rolę odgrywały też zabiegi dyplomatyczne i pomoc konsulatu w zakresie zdobywania niezbędnych pozwoleń, a także udzielania rad co do wyboru najlepszego czasu podróży dla podjęcia badań w tych niespokojnych czasach ${ }^{5}$.

Kreta znalazła się w kręgu zainteresowań archeologicznych École française d'Athènes po roku 1850, kiedy to instytucja ta przeszła pod opiekę Académie des Inscriptions et Belles-Lettres (Akademia Inskrypcji i Literatury Pięknej), towarzystwa naukowego w zakresie nauk humanistycznych ${ }^{6}$. Badania na wyspie zostały wpisane w program Académie, który miał być zrealizowany w latach 1856-1857. Zakładał on trzy wzajemnie się uzupełniające pola badawcze. Po pierwsze, sporządzenie opisu wyspy i poszukiwanie, na podstawie przekazów starożytnych geografów i nowszych badań, starożytnych osad, których lokalizacja nie została jeszcze do tej pory ustalona. Zamierzano również zebrać istniejące na wyspie inskrypcje, a także odwiedzić klasztory, w celu skopiowania zachowanych tam dokumentów. Druga część dotyczyła odtworzenia historii Krety — na podstawie tradycji, przekazu historyków, badań numizmatycznych i znajdujących się tam inskrypcji. Trzecia część planu zakładała badania dotyczące religii, obyczajów, literatury i sztuki, a także studia nad rozmaitymi dialektami, którymi niegdyś się tam posługiwano. W tym zakresie zakładano, że inskrypcje mogą stanowić ciekawy materiał. Zmierzano także do zbadania, czy język, którym posługuje się miejscowa ludność, zachował jeszcze jakieś ślady owych dialektów ${ }^{7}$.

Pierwsza wyprawa wyruszyła na wyspę we wrześniu $1857 \mathrm{r}$. Brali w niej udział Georges Perrot ${ }^{8}$ i Léon Thénon ${ }^{9}$, członkowie École française d'Athènes, którzy

${ }^{4}$ Amédée Daveluy, dyrektor École française d'Athènes, w raporcie napisanym dla ministra zaznaczył, że członkowie wyprawy, Georges Perrot i Léon Thénon, chwalili gościnność, z jaką przyjął ich gubernator wyspy. Zapewnił im bezpłatnych przewodników i wyposażył w konie, co pozwoliło zredukować koszty wyprawy. Zob. K. Christofi, Les Français en Crète. De la huitième question de l'Académie à la consession de Zouroképhalo, „Bulletin de correspondance hellénique” 120, 1996, nr 1, s. 359.

${ }^{5}$ Por. ibidem, s. 358.

${ }^{6}$ Zob. ibidem, s. 357.

${ }^{7}$ Rapport lu à l'Académie des inscriptions et belles-lettres, dans la séance publique du 8 août 1856, au nom de la Commission chagrée d'examiner les travaux envoyés par les membres de l'École française d'Athènes, par M. Guignaut, „Archives des Missions” 5, 1856, s. 653-654.

${ }^{8}$ G. Perrot swoje wspomnienia z wyprawy opisał w książce L'île de Crète: souvenirs de voyage, Paris 1867.

${ }^{9}$ Léon Thénon był francuskim archeologiem i duchownym urodzonym 26 czerwca $1831 \mathrm{r}$. w La Villette, absolwentem l'École normale supérieure. Po zakończeniu udziału w badaniach wykopaliskowych prowadzonych przez francuską szkołę archeologiczną mieszczącą się w Atenach poświęcił się życiu duchownemu, przyjmując święcenia kapłańskie w 1862 r. Zmarł 29 grudnia 1881 w Paryżu. Zob. École Française d'Athènes. Liste Des Élèves, http://www.textesrares.com/philo19/ Ec_ath2.html (dostęp: 3 czerwca 2017). 
byli odpowiedzialni za realizację powyższego programu. Podzielili pomiędzy siebie obowiązki w zależności od zainteresowań. Thénon zajął się wypełnianiem pierwszej części programu, a więc topografią i archeologią wyspy, Perrot zaś historią do czasu podboju Krety przez Saracenów ${ }^{10}$. Przez dwa miesiące ekspedycja przebadała część zachodnią i część centralną wokół góry Ida ${ }^{11}$. Część wschodnią, a także okolice Knossos, pozostawiono na kolejną wyprawę. Jak wynika z relacji uczestników ekspedycji, pierwszy kontakt z wyspą okazał się owocny i dobrze rokował na przyszłość. Udało się zlokalizować pewną liczbę antycznych miast, a także odnaleźć do tej pory nieedytowane inskrypcje ${ }^{12}$. Właśnie wtedy odkryto pierwszy fragment Kodeksu z Gortyny.

Thénon, odwiedzając miejsce, gdzie kiedyś znajdowało się starożytne miasto Gortyna, odkrył inskrypcję umocowaną w murze młyna. Młyn położony był w miejscowości Hagioi Deka na równinie Messara w południowej części Krety. Od samego początku badacza zaciekawił archaiczny wygląd inskrypcji i osobliwy sposób zapisywania alfabetu. Zrobił wierną, na ile było to możliwe, kopię i wrócił do Aten. Studiując tekst inskrypcji, uświadomił sobie wkrótce, że oto znalazł jeden ze starszych pomników języka klasycznego, dokument niezwykle ważny dla epigrafii i filologii greckiej. Zdecydował się nie szczędzić wysiłków, by to cenne znalezisko z odległej przeszłości nie uległo zniszczeniu i aby powiększyć kolekcję inskrypcji ${ }^{13}$.

Badacz powrócił na Kretę wiosną $1858 \mathrm{r}$. Wtedy też wybuchła rewolta przeciwko rządom tureckim. Wybuchu można było się spodziewać, ponieważ już od dawna odczuwalne było niezadowolenie miejscowej ludności. Mimo że Thénon rozumiał skargi ludności chrześcijańskiej, to jednak odczuwał żal z powodu kłopotów, które mogły na długo uniemożliwić wyprawę w głąb wyspy w celu przewiezienia tak cennego dla niego znaleziska ${ }^{14}$.

Do Gortyny powrócił w sierpniu 1858 r., kiedy sytuacja się uspokoiła na tyle, że wyprawa była możliwa. Powrócił też już wówczas do domu kapitan Elias, właściciel młyna i inskrypcji, który przyłączył się do oddziałów powstańczych. Ku uciesze Thénona inskrypcja była na swoim dawnym miejscu. Właściciel zgodził się odstąpić mu cenny kamień, renegocjując jednak na swoją korzyść uzgodnienia z poprzedniego roku. Thénon przetransportował blok do Kandii (obecnie Heraklion). Tam został załadowany na statek i trafił do Luwru ${ }^{15}$.

${ }^{10}$ K. Christofi, op. cit., s. 358.

11 Zob. G. Radet, L'histoire et l'œuvre de l'École française d'Athènes, Paris 1901, s. 343, przypis 4

12 K. Christofi, op. cit., s. 359.

13 Zob. L. Thénon, Une inscription archaïque de Gortyne, „Revue Archéologique” 8, 1863, s. 441 .

14 Ibidem.

15 Ibidem, s. 442. 
Inskrypcja, którą znalazł Thénon, składa się z pięciu linijek tekstu, zachowanego w stanie prawie nienaruszonym, $\mathrm{z}$ wyjątkiem paru liter przy prawej krawędzi ${ }^{16}$. Tekst został wyryty na twardym bloku skalnym, czyli na materiale, w który obfitują pobliskie góry. Styl, w jakim zapisano treść inskrypcji, zwany jest bustrofedonem (dosłownie: „tak jak orzą woły”). Pierwszy wers tak zapisanego tekstu czytano od prawej do lewej, a następny od lewej do prawej. Później okazało się, że inskrypcja odnaleziona przez Thénona stanowi XI kolumnę Kodeksu. Uczonym trudno było odnaleźć satysfakcjonujące znaczenie tejże inskrypcji ${ }^{17}$. W roku 1878 Michel Bréal ustalił, że fragment inskrypcji dotyczy instytucji adopcji ${ }^{18}$.

W następnym roku Bernard Haussoullier ${ }^{19}$ w pobliżu młyna znajdującego się na dawnym miejscu starożytnego miasta Gortyna odnalazł dwie inskrypcje podobne do tych, które odkrył jego rodak. Jedna z nich była wbudowana w dom Daskala Manolakisa, będącego synem kapitana, od którego Thénon zakupił inskrypcję, druga znajdowała się w młynie ${ }^{20}$. Dotyczyły one praw córki dziedziczącej (k. VIII-X).

Owe trzy inskrypcje, które zostały znalezione w tym samym miejscu, w pobliżu młyna, zostały wyryte na trzech blokach, pochodzących z tego samego kamieniołomu ${ }^{21}$. Haussoullier określił, że chodzi o kamieniołom zidentyfikowany jako Labirynt, który znajduje się godzinę drogi od ruin Gortyny ${ }^{22}$. Stało się też dla niego jasne, że pochodzą z tego samego pomnika prawa.

Jak odnotował Haussoullier, można było pokusić się o stwierdzenie, że w miejscu, gdzie za jego czasów stał młyn, kiedyś znajdował się budynek publiczny, na pewno bardzo stary. To z niego pochodzily bloki skalne, które można dostrzec niedaleko spadku wody. Wszystkie zostały tam zgromadzone, aby wzmocnić brzegi kanału i uregulować przepływ wody. Nie wiadomo było, z jakiej części starożytnego miasta pochodziły, Haussoullier zakładał jednak, że były częścią tej samej budow$1 i^{23}$. Było zatem jasne, że inskrypcje, którymi się zajmował, były analogiczne do tej, którą odnalazł Thénon: wykonane z tego samego kamienia, zawierające zapis o tym samym charakterze, mówiące o prawie. Dla Haussoulliera nie ulegało wątpliwości,

16 Analiza tejże inskrypcji zob. ibidem, s. 445-447.

17 Zob. Fragment d'une ancienne loi crétoise sur les héritages, [w:] Les Inscriptions Grecques interprétées par W. Froehner, Paris 1865, s. 180-181; H. Voretzsch, Die Busteophedoninscheift von Gortyn, „Jahrbücher für classische Philologie” 15, 1869, s. 665-679; J. Savelsberg, Die Busteophedoninscheift von Gortyn, „Jahrbücher für classische Philologie” 15, 1869, s. 679-694; M. Bréal, Un ancien de loi de la Crète, ,Revue archéologique” 36, 1878, s. 346-355.

${ }^{18}$ M. Bréal, op. cit.

${ }^{19} \mathrm{Na}$ temat kariery naukowej Haussoulliera zob. P. Jouguet, Bernard Haussoullier, „École pratique des hautes études. Section des sciences historiques et philologiques" 60/1, 1927, s. 3-14.

${ }^{20} \mathrm{~B}$. Haussoullier, Inscriptions archaïques de Gortyne (Crète), „Bulletin de correspondance hellénique" 4, 1880, $\mathrm{nr}$ 1, s. 461.

21 Ibidem.

22 V.G. Perrot, op. cit., s. 99.

${ }^{23}$ B. Haussoullier, op. cit., s. 461. 
że pochodzą one z tego samego czasu i sięgają do bardzo odległej przeszłości. Być może zostały one wyryte na fundamentach budynku publicznego ${ }^{24}$.

Kolejną część inskrypcji odkrył w lipcu 1884 włoski archeolog z Uniwersytetu w Rzymie, Federico Halbherr, będący uczniem Domenica Comparettiego, który pod auspicjami włoskiego rządu prowadził badania archeologiczne nieopodal młyna. Szczęście mu sprzyjało, gdyż z uwagi na niezbędne naprawy osuszono kanał. Tak więc w korycie kanału jego oczom ukazał się mur. Zauważywszy w górnej jego części litery, Halbherr rozpoczął prace i w ten sposób odkrył cztery kolejne kolumny, ułożone we właściwym porządku. Ostatnia kolumna nie była do końca zapisana, co wskazywało na to, że w tym miejscu inskrypcja się kończyła. Tak więc cztery ostatnie kolumny Kodeksu (IX-XII) zostały odkryte. Archeolog wiedział, że inskrypcje ciągnęły się w drugą stronę, w kierunku wschodnim, ale nie otrzymał wówczas pozwolenia od właściciela gruntu na eksplorację w tamtym kierunku. Sfrustrowany pisał do Comparettiego: „L'ignoranza, le pretensioni, la malignità di certe gente non si possono immaginare da chi non tratta direttamente con essi" 25 . Halbherrowi pozostały dwa dni, podczas których w kanale nie było wody, mógł więc przekopiować odsłonięte kolumny.

W tym czasie na wyspie przebywał Ernst Fabricius, który zobaczywszy kopie sporządzone przez Halbherra, przekonał właściciela ziemi, aby zezwolił na odkrycie dalszej części muru. Przy odsłanianiu pięciu kolejnych bloków archeolodzy nie natrafili na problemy. Przy następnym przeszkodą okazało się drzewo morwowe rosnące powyżej bloków, na których wyryte były trzy pierwsze kolumny Kodeksu. Fabricius nie otrzymał zgody na usunięcie drzewa. Musiał znaleźć inne rozwiązanie, które pozwoliłoby osiągnąc $\mathrm{cel}^{26}$. Przez kolejne dni Fabricius, brodząc w wodzie na dnie trzyipółmetrowego rowu, kopiował całość odsłoniętej inskrypcji. Fragment inskrypcji odkrytej przez Halbherra i Fabriciusa składał się z 29 bloków tworzących zakrzywiony mur. Wcześniej odkryte fragmenty stanowiły górną część kolumn VII-IX.

Sporządziwszy kopie, obaj uczeni porównali je z oryginałem, zanim znowu został zakryty, a także przekazali je sobie nawzajem ${ }^{27}$. Zarówno kopie Fabriciusa, jak i Halbherra zostały niebawem wydane drukiem. Fabricius sam opublikował inskrypcję w roku $1884^{28}$. Kopia Halbherra została opublikowana przez jego

${ }^{24}$ Ibidem, s. 471.

${ }^{25}$ D. Comparetti, Inscrizioni Arcaiche di Gortyna, „Museo Italiano di antichità classica” 1, 1885, s. 233.

26 E. Fabricius, Alterthümer auf Kreta: I. Gesetz von Gortyn, „Mittheilungen des Deutschen Archäologischen Instituts. Athenische Abteilung" 9, 1884, nr 4, s. 364-365.

${ }^{27}$ H.J. Roby, The twelve tables of Gortyn, „The Law Quarterly Review” 1886, nr 2, s. 135.

${ }^{28}$ E. Fabricius, op. cit., s. 364-365. 
mentora, Comparettiego, w $1885^{29}$. Zaczęły także pojawiać się następne edycje, thumaczenia na języki nowożytne i komentarze do Kodeksu ${ }^{30}$.

Halbherr w następnym roku kontynuował badania, które w kolejnych latach musiał jednak przerwać z uwagi na sytuację polityczną panującą na wyspie ${ }^{31}$. Jakiś czas później, w maju roku 1893, Archaeological Institute of America powierzył mu misję przebadania Krety. Jego wybór był spowodowany m.in. faktem, że Halbherr prowadził tam prace w latach 1884-1886, podczas których, obok wielu innych inskrypcji, odkryto również największą część Kodeksu z Gortyny ${ }^{32}$. Ame-

29 D. Comparetti, op. cit., s. 233-287.

${ }^{30}$ W tym miejscu należy wskazać: F. Halbherr, E. Fabricius, D. Comparetti, Leggi antiche della città di Gortyna in Creta, Firenze 1885; F. Bücheler, E. Zitelmann, Das Recht von Gortyn, Frankfurt am Main 1885; J. Baunack, T. Baunack, Die Inschrift von Gortyn, Leipzig 1885; H. Lewy, Altes Stadtrecht von Gortyn, Berlin 1885; R. Dareste de la Chavannes, La loi de Gortyne, „Bulletin de correspondance hellénique" 1885, nr 9, s. 301-317; R. Dareste de la Chavannes, La loi de Gortyne, texte, traduction, commentaire, „Annuaire de l'Association pour l'encouragement des études grecques en France” 1886, nr 20; A.C. Merriam, Law code of the Kretan Gortyna (I), „The American Journal of Archaeology and of the History of the Fine Arts" 1, 1885, nr 4, s. 324-350; A.C. Merriam, Law code of the Kretan Gortyna (II), „The American Journal of Archaeology and of the History of the Fine Arts" 2, 1886, nr 1, s. 24-45; F. Bernhöft, Die Inschrift von Gortyn, Stuttgart 1886; H.J. Roby, op. cit., s. 135-152; J. Simon, Zur Inschrift von Gortyn, Wien 1886; J. Kohler, E. Ziebarth, Das Stadtrecht von Gortyn und seine Beziehungen zum gemeingriechischen Rechte, Göttingen 1912; R.F. Willets, The Law Code of Gortyn (Kadmos Supplement I), Berlin 1967. M. Kuryłowicz zamieścił Przeglad treści Ustawy z Gortyny (w streszczeniu) w swojej książce Prawa antyczne. Wyktady z historii najstarszych praw świata, Lublin 2006, s. 153-157. Fragment dotyczący adopcji przetłumaczył i omówił J. Rominkiewicz, Adopcja w kodeksie z Gortyny, „Prawo” 316/2, Wrocław 2014, s. 27-38.

${ }^{31}$ L. Pernier, Scavo dell'Edificio della Grande Inscrizione nell'Agora di Gortina, „Annuario della Regia Scuola Archaeologica di Atene e delle Missioni Italiane in Oriente" 1, 1914, s. 373.

32 Zob. American expedition to Krete under Professor Halbherr, „American Journal of Archaeology and of the History of the Fine Arts" 9, 1894, nr 4, s. 538. Sprawozdania z wykopalisk archeologicznych prowadzonych w ramach tej misji znajdują się w serii artykułów opublikowanych w „American Journal of Archaeology” w latach 1896-1902 (do 1896 jako „The American Journal of Archaeology and of the History of the Fine Arts"): F. Halbherr, Report on the expedition of the institute to Crete, AJA 11, 1896, nr 4, s. 525-538; F. Halbherr, Cretan expedition. I. Inscriptions from various Cretan cities, AJA 11, 1896, nr 4, s. 539-601; F. Halbherr, Cretan expedition. II. Christian inscriptions, AJA 11, 1896, nr 4, s. 602-613; F. Halbherr, Cretan expedition III. Epigraphical researches in Gortyna, AJA 1, 1897, nr 3, s. 159-238; F. Halbherr, Cretan expedition IV. Some Cretan sculptures in the Museum of the Syllogos of Candia, AJA 1, 1897, nr 3, s. 239-250; F. Halbherr, Cretan expedition V. Note on a Mycenaean vase and on some geometric vases of the Syllogos of Candia, AJA 1, 1897, nr 3, s. 251-265; P. Orsi, Cretan expedition VI. Some Roman busts in the Museum of the Syllogos of Candia, AJA 1, 1897, nr 3, s. 266-278; L. Mariani, Cretan expedition VII. Statue of an Asclepiad from Gortyna, AJA 1, 1897, nr 3, s. 279-285; A. Taramelli, Cretan expedition VIII. The prehistoric grotto at Miamù, AJA 1, 1897, $\mathrm{nr}$ 4-5, s. 287-312; S.A. Xanthoudidis, Cretan expedition IX. Inscriptions from Gortyna, Lyttos, and Lató Pros Kamara, AJA 2, 1898, nr 1-2, s. 71-78; F. Halbherr, Cretan expedition X. Addenda to the Cretan inscriptions, AJA 2, 1898, nr 1-2, s. 79-94; F. Halbherr, Cretan expedition XI. Three Cretan necropoleis: Report on the researches at Erganos, Panaghia, and Courtes, AJA 5, 1901, nr 3, s. 259-293; A. Taramelli, Cretan expedition XII. Notes on the necropolis of Courtes, AJA 5, 1901, nr 3, s. 294-301; L. Mariani, Cretan expedition XIII. The 
rykańscy uczeni byli bardzo zainteresowani nowym znaleziskiem, a prof. Augustus C. Merriam był jednym z pierwszych, którzy zajęli się interpretacją Kodeksu. W ten sposób Amerykanie włączyli się w badania archeologiczne, które dzięki uczonemu z La Sapienzy miały stanowić m.in. kontynuację prac prowadzonych przez Włochów w latach 1884-1886. Badania miały głównie koncentrować się na eksploracji gortyńskiej agory i rzymskiego teatru, czyli miejsca związanego z Kodeksem. Zakładano, że będą one trwały około sześciu miesięcy ${ }^{33}$. Halbherr przybył na Kretę jesienią 1893 r. i dostrzegł, że sytuacja polityczna uległa zmianie w stosunku do tej, jaka panowała na wyspie podczas jego wcześniejszego pobytu, co miało negatywne konsekwencje dla prowadzonych badań. Podczas gdy poprzednie władze, jak relacjonował Halbherr, były pozytywnie nastawione do badań naukowych, obecne były niezwykle niechętne ${ }^{34}$. Negocjacje w sprawie wykopalisk znacznie się przeciągały, co zmusiło uczonego do zmiany planów. Pierwsze miesiące spędził na przemierzaniu mało znanych zakątków wyspy, kopiowaniu do tej pory jeszcze niepublikowanych inskrypcji i badaniu pozostałości kultury starożytnej. Badanie miejsca, w którym prawie dekadę wcześniej odnalazł Kodeks, było utrudnione na skutek postawy mieszkańców, którzy niechętnie odnosili się do pomysłu ingerencji w bieg strumienia zasilającego młyn ${ }^{35}$.

Halbherr współpracował także z Towarzystwem Przyjaciół Edukacji (Philekpaideutikos Syllogos), które powierzyło mu publikację zbioru znajdujących się na Krecie inskrypcji ${ }^{36}$. Halbherr spodziewał się, że na tym terenie muszą istnieć inne inskrypcje o tematyce prawnej, być może nawet całe sekcje wyryte na nieodsłoniętych jeszcze ścianach ${ }^{37}$. Ścianę z Kodeksem i grunt, na którym ją odkryto, udało się nabyć pod koniec czerwca $1893 \mathrm{r}^{38}$

Badania archeologiczne były prowadzone również w latach 1899-1900. Odkryto wówczas wschodnią i północną ścianę hellenistycznej budowli, wykorzy-

vases of Erganos and Courtes, AJA 5, 1901, nr 3, s. 302-314; G. Sergi, Cretan expedition XIV. Notes upon the skulls of Erganos, AJA 5, 1901, nr 3, s. 315-318; G. de Sanctis, Cretan expedition XV. The Startus in the Cretan inscriptions, AJA 5, 1901, nr 3, s. 319-327; F. Halbherr, Cretan expedition XVI. Report on the researches at Praesos, AJA 5, 1901, nr 4, s. 371-392; F. Halbherr, Cretan expedition XVII. Ruins of unknown cities at Haghios Ilias and Prinià, AJA 5, 1901, nr 4, s. 393-403; L. Savignoni, Cretan expedition XVIII. Fragments of Cretan Pithoi, AJA 5, 1901, nr 4, s. 404-417; A. Taramelli, Cretan expedition XIX. A visit to Phaestos, AJA 5, 1901, nr 4, s. 418-436; A. Taramelli, Cretan expedition XX. A visit to the grotto of camares on Mount Ida, AJA 5, 1901, nr 4, s. 437-451;

A. Taramelli, Cretan expedition: XXI Gortyna, AJA 6, 1902, nr 2, s. 101-165.

${ }^{33}$ F. Halbherr, Report on the expedition of the institute to Crete..., s. 526.

${ }^{34}$ Ibidem, s. 526-528.

${ }^{35}$ American expedition to Krete under Professor Halbherr..., s. 538.

36 Ibidem.

37 Ibidem, s. 539.

38 Ibidem, s. 541. Towarzystwo zwracało się o pomoc finansową do różnych instytucji, m.in. za pośrednictwem „American Journal of Philology”. Zob. List prezesa „The Greek Syllogos of Candia” dra Josepha Hazzidakisa z 24 grudnia 1893 r., „American Journal of Philology” 15, 1894, s. $121-122$. 
staną później w budowli przeznaczonej na występy muzyczne (odeon) z czasów rzymskich. Dokładne przebadanie tego miejsca wymagało jednak szeroko zakrojonych prac, mających na celu zmianę biegu strumienia, które odbywały się przy zaangażowaniu Kreteńczyków oraz Włochów i zostały zakończone w 1911 r. Były one niezbędne z uwagi na to, że strumień przekraczał pozostałości odeonu w paru miejscach. Przeprowadzone prace umożliwiły Luigiemu Pernierowi i Scuola Archeologica Italiana di Atene prowadzenie dalszych badań w latach 1911-1914 ${ }^{39}$.

W 1920 r. Enrico Stefani podjął się zadania rekonstrukcji odeonu, tym samym zabezpieczając teren wokół inskrypcji ${ }^{40}$. Halbherr w roku 1922 częściowo zdemontował ścianę odeonu w celu odnalezienia inskrypcji, o których wiedział już w roku $1914^{41}$. Wśród nich była inskrypcja oznaczona jako IC.IV.73 ${ }^{42}$.

Odeon był zlokalizowany na południowy wschód od gortyńskiego akropolu, na wschód od rzeki Lethaios. Obszar ten został zidentyfikowany jako agora. Badania przeprowadzone przez Halbherra i Perniera wykazały, że teren w okolicy odeonu stał się centrum publicznym pod koniec VI w. p.n.e. To tam miałaby znajdować się w okresie archaicznym i klasycznym agora gortyńskiej polis ${ }^{43}$. Potwierdzają to m.in. odnalezione w tym miejscu inskrypcje $\mathrm{e}^{44}$.

Ani okoliczności, ani dokładny czas powstania inskrypcji nie są znane. Uczeni datują ją na ogół na V w. p.n.e. Zdaniem Margherity Guarducci, będącej uczennicą Halbherra, Kodeks powstał między 480 a 460 r. p.n.e. ${ }^{45}$ Paręset lat po wykonaniu inskrypcja zmieniła swoją lokalizację. Gortyna wówczas stanowiła stolicę rzymskiej Krety po podboju wyspy przez Kwintusa Cecyliusza Metellusa w 67 r. p.n.e. Mur złożony z 31 bloków, na których wyryty jest Kodeks, został starannie

39 P.J. Perlman, op. cit., s. 181.

40 L. Pernier, L',,Odeum” nell',,Agorà” di Gortina presso il Leteo, „Annuario della Regia Scuola Archeologica di Atene e delle Missioni Italiane in Oriente" 8-9, 1925-1926, s. 1-69.

41 V. La Rosa, C'era dell'altro all'interno della grande iscrizione di Gortina. Ed era stato recuperato, „Creta Antica” 3, 2002, s. 277.

42 Zob. M. Guarducci, Inscriptiones Creticae: Opera et Consilio Friderici Halbherr Collectae, t. 4. Tituli Gortynii, Roma 1950, s. 171-173.

43 P.J. Perlman, Gortyn. The First Seven Hundred Years, cz. 1, [w:] Polis and Politics: Studies in Ancient Greek History, red. P. Flensted-Jensen, T. Heine Nielsen, L. Rubinstein, Copenhagen 2000, s. 72; A. Di Vita, Gortina di Creta: Quindici Secoli di Vita Urbana, Rome 2010, s. 38-39.

44 IC.IV.62-64, IC.IV.41-61, IC.IV.65-71.

45 Uczeni wskazywali różny czas powstania Kodeksu. Początkowo z uwagi na bardzo archaiczny wygląd mówiono nawet o VII w. p.n.e. Zob. E. Caillemer, s.v. Gortyniorum leges, [w:] Dictionnaire des antiquités grecques et romaines, d'après les textes et les monuments, II 2, C.V. Daremberg, red. E. Saglio, Paris 1896, s. 1630. Comparetti datował to prawo na pierwszą połowę VI w. p.n.e. - Le leggi di Gortyna e le altre iscrizioni arcaiche Cretesi edite ed illustrate da Domenico Comparetti (Monumenti antichi pubblicati per cura della Reale Accademia dei Lincei, t. 3), Milano 1893, s. 372. Na drugą połowę V w. p.n.e. datuje tę inskrypcję Kirchhoff, a za nim Dareste. Zob. T. Reinach, B. Haussoullier, R. Dareste, Recueil des inscriptions juridiques grecques, t. 3, Paris 1894, s. 439. Na temat datacji Kodeksu zob. R.F. Willetts, op. cit., s. 8. 
przeniesiony ze swojego pierwotnego miejsca i ustawiony w przejściu odeonu ${ }^{46}$. Wykorzystywanie bloków skalnych z inskrypcjami jako materiału budulcowego było w późniejszych czasach zjawiskiem często praktykowanym. Odnaleziono wiele starożytnych inskrypcji prawnych, które zostały wkomponowane w późniejsze konstrukcje. Interesujące jest jednak, że przy wykorzystaniu płyt skalnych z omawianą inskrypcją nie zdano się na przypadek, lecz została ona niezwykle starannie zrekonstruowana i umieszczona w ramach odeonu. Budowniczowie mieli wszelako ułatwione zadanie, gdyż bloki i kolumny zostały ponumerowane ${ }^{47}$.

Badacze zastanawiają się, jaki charakter pełniła budowla, w której pierwotnie była ulokowana inskrypcja. Ustalono, że była to okrąła budowla, która mogła służyć jako miejsce spotkań mieszkańców Gortyny, być może ekklesiasterion ${ }^{48}$. Jak założył Antonio Di Vita, znaczna część bloków z inskrypcją, pochodzącą z okrągłego budynku z czasów wcześniejszych, została wcielona do hellenistycznego buleuterionu, czyli miejsca, gdzie zbierała się rada (bule $)^{49}$. Czas zburzenia buleuterionu był przedmiotem licznych dyskusji. Zdaniem Di Vity budynek został rozebrany nie wcześniej niż w połowie I w. p.n.e. ${ }^{50}$ Mógł być jednak także po pewnych przeróbkach używany jako odeon ${ }^{51}$.

Gortyński odeon jest budowlą z okresu rzymskiego, parokrotnie przebudowaną, zajmującą to samo miejsce na agorze, które wcześniej zajmowały buleuterion i ekklesiasterion. Do czasu, gdy Di Vita przeprowadził w Gortynie w 1997 r. i później w 2004 prace wykopaliskowe, uważano, że odeon został zbudowany w okresie Augusta, następnie został zniszczony i później odbudowany za czasów Trajana $^{52}$. Di Vita, przyjmując tę sekwencję wydarzeń, uznał ponadto, że odeon został także przebudowany za panowania cesarzy z dynastii Antoninów lub Sewerów $^{53}$. W czasach rzymskich, kiedy inskrypcja znalazła się w odeonie, została umieszczona w ciemnym, w zasadzie podziemnym przejściu, gdzie mogli ją zobaczyć przechodzący tamtędy widzowie ${ }^{54}$.

${ }^{46}$ C.E. Gorlin, The Gortynian Law Code and Roman Crete, dysertacja doktorska, Brown University, 1991, s. 1.

${ }^{47}$ Zob. P. Keyser, Numerals on the Gortynian law-codes (IC IV $\left.72+73\right)$, „Zeitschrift für Papyrologie und Epigraphik" 69, 1987.

48 Zob. Ch. Clark, The Gortyn Laws in Architectural Context, 2011, s. 66, c, https://classics. dartmouth.edu/sites/classics.dartmouth.edu/files/Charles\%20Clark\%20Thesis\%202011.pdf (dostęp: 23 października 2017).

49 A. Di Vita, op. cit., s. 52.

50 Ibidem, s. 51.

51 C.E. Gorlin, op. cit., s. 15.

52 I.F. Sanders, Roman Crete: An Archaeological Survey and Gazetteer of Late Hellenistic, Roman, and Early Byzantine Crete, Warminster 1982, s. 65-66; C.E. Gorlin, op. cit., s. 7.

53 A. Di Vita, op. cit., s. 108-110.

${ }^{54}$ Ch. Clark, op. cit., s. 88. Gorlin wysunęła tezę, że przepisy Kodeksu pozostały w mocy także za rzymskiego panowania, a przeniesienie Kodeksu stanowiło formę jego ponownej promulgacji o oficjalnym charakterze (op. cit., s. 7). 
Kodeks został wyryty na 12 kolumnach. Każda kolumna składa się z czterech rzędów kamieni. Są jednak ślady wskazujące na to, że w oryginalnym budynku, w którym początkowo znajdowała się inskrypcja, był piąty rząd. W niektórych kolumnach (IV, VI, VII, VIII) ostatnia linijka zawiera ucięte litery — prawdopodobnie dlatego, że ich dalsza część znajdowała się właśnie na piątym rzędzie kamieni w oryginalnym budynku. Piąty rząd nie został już wykorzystany w nowym budynku. Mógł być natomiast użyty w innej konstrukcji ${ }^{55}$. Zgodnie z ustaleniami Di Vity, ten dolny rząd inskrypcji gdzieś w I w. n.e. został zniszczony i utracony ${ }^{56}$.

Długość całej inskrypcji wynosi ponad dziewięć metrów. Każda kolumna ma około $165-170 \mathrm{~cm}$ wysokości i około $65 \mathrm{~cm}$ szerokości. Każda z nich, z wyjątkiem ostatniej, zawiera od 53 do 65 wersów. Ostatnia, dwunasta, liczy 36 wersów, a całość - ponad $600^{57}$. Pierwsza linia każdej kolumny biegnie od strony prawej do lewej, a całą inskrypcję należy czytać zgodnie ze wzorem bustrofedonu. Alfabet, w którym spisano prawo, liczy 18 liter. Poszczególne litery mierzą około $3 \times 3 \mathrm{~cm}$. Pierwszy wers kolumny I jest inwokacją do bogów. Przepisy Kodeksu dotyczą sytuacji prawnej osób, pewnych aspektów prawa procesowego, prawa rodzinnego, spadkowego, regulują także własność i prawo zastawu. Struktura Kodeksu była przedmiotem licznych dywagacji uczonych ${ }^{58}$.

Odnalezienie Kodeksu z Gortyny pod koniec XIX w. było dziełem przypadku, jednak wiązało się z szeroko zakrojonymi badaniami archeologicznymi prowadzonymi na wyspie przez Francuzów, Niemców i Włochów. Największy jej fragment został odnaleziony przez włoskiego uczonego, Halbherra, zatem to on jest uznawany za jego odkrywcę, chociaż nie można zapominać o wkładzie francuskich uczonych, którzy działali niezależnie, a także o pomocy udzielonej przez Fabriciusa. Halbherr, obok Arthura Evansa, który odkrył przed nami skarby minojskiego świata, jest ważną postacią w historii kreteńskiej archeologii. Godne uwagi jest, że także miejscowa ludność interesowała się dziedzictwem, co może być rozpatrywane przez pryzmat tureckiej okupacji wyspy, czy też znacznej ingerencji państw europejskich. Szczególne znaczenie w tym zakresie ma Towarzystwo Przyjaciół Edukacji, na którego bazie później powstało Muzeum Archeologiczne w Heraklionie.

Inskrypcja została odnaleziona w okolicy miejscowości Hagioi Deka. Wiele tamtejszych budowli zostało skonstruowanych przy użyciu materiałów pochodzących z pozostałości antycznego miasta Gortyna. Już od momentu, w którym odnaleziono pierwszy fragment, inskrypcja stała się przedmiotem zainteresowania zarówno filologów, jak i historyków prawa. Zainteresowanie to nie słabnie. Cho-

55 R.F. Willets, op. cit., s. 4.

${ }^{56}$ A. Di Vita, op. cit., s. 118.

57 Zob. R.F. Willets, op. cit., s. 3-4. Dokładny opis: Ch. Clark, op. cit., s. 15-22.

58 Zob. R.F. Willets, op. cit., s. 4; M. Gagarin, The organization of the Gortyn law code, „Greek, Roman and Byzantine Studies” 23, 1982, nr 2, s. 129-146; K.R. Kristensen, Codification, tradition, and innovation in the law code of Gortyn, „Dike” 7, 2004, s. 135-168. 
ciaż na Krecie odnaleziono wiele interesujących inskrypcji, mówiących o prawie publicznym, deliktach, procedurze czy o prawie rodzinnym, ta jednak jest niezwykła z uwagi na rozmiary i stan zachowania.

\section{Bibliografia}

American expedition to Krete under Professor Halbherr, „American Journal of Archaeology and of the History of the Fine Arts" 9, 1894, nr 4.

Baunack J., Baunack T., Die Inschrift von Gortyn, Leipzig 1885.

Bernhöft F., Die Inschrift von Gortyn, Stuttgart 1886.

Bréal M., Un ancien de loi de la Crète, „Revue archéologique” 36, 1878.

Bücheler F., Zitelmann E., Das Recht von Gortyn, Frankfurt am Main 1885.

Caillemer E., s.v. Gortyniorum leges, [w:] Dictionnaire des antiquités grecques et romaines, d'après les textes et les monuments, II 2, C.V. Daremberg, red. E. Saglio, Paris 1896.

Christofi K., Les Français en Crète. De la huitième question de l'Académie à la consession de Zouroképhalo, „Bulletin de correspondance hellénique” 120, 1996, nr 1.

Clark Ch., The Gortyn Laws in Architectural Context, 2011, s. 66, https:/classics.dartmouth.edu/sites/ classics.dartmouth.edu/files/Charles\%20Clark\%20Thesis\%202011.pdf (dostęp: 23 października 2017).

Comparetti D., Inscrizioni Arcaiche di Gortyna, „Museo Italiano di antichità classica” 1, 1885.

Dareste de la Chavannes R., La loi de Gortyne, „Bulletin de correspondance hellénique” 1885, nr 9.

Dareste de la Chavannes R., La loi de Gortyne, texte, traduction, commentaire, „Annuaire de l'Association pour l'encouragement des études grecques en France" 1886, nr 20.

Di Vita A., Gortina di Creta: Quindici Secoli di Vita Urbana, Rome 2010.

Fabricius E., Alterthümer auf Kreta: I. Gesetz von Gortyn, „Mittheilungen des Deutschen Archäologischen Instituts. Athenische Abteilung" 9, 1884, nr 4.

Fragment d'une ancienne loi crétoise sur les héritages, [w:] Les Inscriptions Grecques interprétées par W. Froehner, Paris 1865.

Gagarin M., The organization of the Gortyn law code, „Greek, Roman and Byzantine Studies” 23, $1982, \mathrm{nr} 2$.

Gorlin C.E., The Gortynian Law Code and Roman Crete, dysertacja doktorska, Brown University, 1991.

Guarducci M., Inscriptiones Creticae: Opera et Consilio Friderici Halbherr Collectae, t. 4. Tituli Gortynii, Roma 1950.

Halbherr F., Cretan expedition. I. Inscriptions from various Cretan cities, AJA 11, 1896, nr 4.

Halbherr F., Cretan expedition. II. Christian inscriptions, AJA 11, 1896, nr 4.

Halbherr F., Cretan expedition III. Epigraphical researches in Gortyna, AJA 1, 1897, nr 3.

Halbherr F., Cretan expedition IV. Some Cretan sculptures in the Museum of the Syllogos of Candia, AJA 1, 1897, nr 3.

Halbherr F., Cretan expedition V. Note on a Mycenaean vase and on some geometric vases of the Syllogos of Candia, AJA 1, 1897, nr 3.

Halbherr F., Cretan expedition X. Addenda to the Cretan inscriptions, AJA 2, 1898, nr 1-2.

Halbherr F., Cretan expedition XI. Three Cretan necropoleis: Report on the researches at Erganos, Panaghia, and Courtes, AJA 5, 1901, nr 3.

Halbherr F., Cretan expedition XVI. Report on the researches at Praesos, AJA 5, 1901, nr 4.

Halbherr F., Cretan expedition XVII. Ruins of unknown cities at Haghios Ilias and Prinià, AJA 5, 1901, nr 4. 
Halbherr F., Report on the expedition of the institute to Crete, AJA 11, 1896, nr 4.

Halbherr F., Fabricius E., Comparetti D., Leggi antiche della città di Gortyna in Creta, Firenze 1885.

Haussoullier B., Inscriptions archaïques de Gortyne (Crète), „Bulletin de correspondance hellénique" 4, 1880, nr 1.

Hazzidakis J., The Greek Syllogos of Candia, „American Journal of Philology” 15, 1894.

Jouguet P., Bernard Haussoullier, „École pratique des hautes études. Section des sciences historiques et philologiques" 60/1, 1927.

Keyser P., Numerals on the Gortynian law-codes (IC IV $72+73$ ), „Zeitschrift für Papyrologie und Epigraphik" 69, 1987.

Kohler J., Ziebarth E., Das Stadtrecht von Gortyn und seine Beziehungen zum gemeingriechischen Rechte, Göttingen 1912.

Kristensen K.R., Codification, tradition, and innovation in the law code of Gortyn, „Dike” 7, 2004.

Kuryłowicz M., Prawa antyczne. Wykłady z historii najstarszych praw świata, Lublin 2006.

La Rosa V., C'era dell'altro all'interno della grande iscrizione di Gortina. Ed era stato recuperato, „Creta Antica” 3, 2002.

Le leggi di Gortyna e le altre iscrizioni arcaiche Cretesi edite ed illustrate da Domenico Comparetti (Monumenti antichi pubblicati per cura della Reale Accademia dei Lincei, t. 3), Milano 1893.

Lewy H., Altes Stadtrecht von Gortyn, Berlin 1885.

Mariani L., Cretan expedition VII. Statue of an Asclepiad from Gortyna, AJA 1, 1897, nr 3.

Mariani L., Cretan expedition XIII. The vases of Erganos and Courtes, AJA 5, 1901, nr 3.

Merriam A.C., Law code of the Kretan Gortyna (I), „The American Journal of Archaeology and of the History of the Fine Arts" 1, 1885, nr 4.

Merriam A.C., Law code of the Kretan Gortyna (II), „The American Journal of Archaeology and of the History of the Fine Arts" 2, 1886, nr 1.

Orsi P., Cretan expedition VI. Some Roman busts in the Museum of the Syllogos of Candia, AJA 1, 1897, nr 3.

Perlman P.J., Gortyn. The First Seven Hundred Years, cz. 1, [w:] Polis and Politics: Studies in Ancient Greek History, red. P. Flensted-Jensen, T. Heine Nielsen, L. Rubinstein, Copenhagen 2000.

Perlman P.J., Writing on the Walls. The Architectural Context of Archaic Cretan Laws, [w:] Crete beyond the Palaces: Proceedings of the Crete 2000 Conference, red. L. Preston Day, M.S. Mook, J.D. Muhly, Philadelphia 2004.

Pernier L., L',,Odeum” nell ',Agorà ” di Gortina presso il Leteo, „Annuario della Regia Scuola Archeologica di Atene e delle Missioni Italiane in Oriente" 8-9, 1925-1926.

Pernier L., Scavo dell'Edificio della Grande Inscrizione nell'Agora di Gortina, „Annuario della Regia Scuola Archaeologica di Atene e delle Missioni Italiane in Oriente" 1, 1914.

Perrot G., L'île de Crète: souvenirs de voyage, Paris 1867.

Radet G., L'histoire et l'œuvre de l'École française d'Athènes, Paris 1901.

Rapport lu à l'Académie des inscriptions et belles-lettres, dans la séance publique du 8 août 1856 , au nom de la Commission chagrée d'examiner les travaux envoyés par les membres de l'École française d'Athènes, par M. Guignaut, „Archives des Missions” 5, 1856.

Reinach T., Haussoullier B., Dareste R., Recueil des inscriptions juridiques grecques, t. 3, Paris 1894.

Roby H.J., The twelve tables of Gortyn, „The Law Quarterly Review” 1886, nr 2.

Rominkiewicz J., Adopcja w kodeksie z Gortyny, „Prawo” 316/2, Wrocław 2014.

Sanctis G. de, Cretan expedition XV. The Startus in the Cretan inscriptions, AJA 5, 1901, nr 3.

Sanders I.F., Roman Crete: An Archaeological Survey and Gazetteer of Late Hellenistic, Roman, and Early Byzantine Crete, Warminster 1982.

Savelsberg J., Die Busteophedoninscheift von Gortyn, „Jahrbücher für classische Philologie” 15, 1869.

Savignoni L., Cretan expedition XVIII. Fragments of Cretan Pithoi, AJA 5, 1901, nr 4. 
Sergi G., Cretan expedition XIV. Notes upon the skulls of Erganos, AJA 5, 1901, nr 3.

Simon J., Zur Inschrift von Gortyn, Wien 1886.

Taramelli A., Cretan expedition VIII. The prehistoric grotto at Miamù, AJA 1, 1897, nr 4-5.

Taramelli A., Cretan expedition XII. Notes on the necropolis of Courtes, AJA 5, 1901, nr 3.

Taramelli A., Cretan expedition XIX. A visit to Phaestos, AJA 5, 1901, $\mathrm{nr} 4$.

Taramelli A., Cretan expedition XX. A visit to the grotto of camares on Mount Ida, AJA 5, 1901, nr 4. Taramelli A., Cretan expedition: XXI Gortyna, AJA 6, 1902, nr 2.

Thénon L., Une inscription archaïque de Gortyne, „Revue Archéologique” 8, 1863.

Voretzsch H., Die Busteophedoninscheift von Gortyn, „Jahrbücher für classische Philologie” 15, 1869.

Willets R.F., The Law Code of Gortyn (Kadmos Supplement I), Berlin 1967.

Xanthoudidis S.A., Cretan expedition IX. Inscriptions from Gortyna, Lyttos, and Lató Pros Kamara, AJA 2, 1898, nr 1-2.

\section{The twelve columns of Gortyn — history of the discovery}

\section{Summary}

The article is devoted to the history of the discovery of the so-called Code of Gortyn, which has attracted the interest of philologists and historians of law. The Code of Gortyn was discovered in the late 19th century by chance, yet the discovery was linked to large-scale archaeological research conducted on the island by the French, Germans and Italians. Its most extensive fragment was found by the Italian scholar Frederico Halbherr, who is consequently regarded as its discoverer, although we should not forget about the contributions of French scholars working independently, about the assistance provided by Ernst Fabricius and about the contributions of local scholars.

Keywords: Code of Gortyn, Gortyn, Frederico Halbherr, Crete

\section{Die zwölf Säulen aus Gortys — Geschichte der Entdeckung}

\section{Zusammenfassung}

Gegenstand des Beitrags ist die Geschichte der Entdeckung des sog. Stadtrechtes von Gortys, das seitdem Gegenstand der Interesse der Philologen und Rechtshistoriker ist. Die Entdeckung der Inschrift am Ende des 19. Jahrhunderts in Gortys war ein reiner Zufall, obwohl sie doch mit den breit angelegten archäologischen Untersuchungen, die auf Kreta durch die Franzosen, Deutschen und Italiener geführt waren, im Zusammenhang stand. Der größte Teil der Inschrift wurde durch den italienischen Wissenschaftler Frederico Halbherr gefunden, so gilt er als ihr Entdecker. Der Beitrag der französischen Wissenschaftler, die unabhängig handelten, sowie die Hilfe seitens Ernst Fabricius und auch der Beitrag des örtlichen wissenschaftlichen Milieus dürfen jedoch dabei nicht vergessen werden.

Schlüsselworte: Stadtrecht aus Gortys, Gortys, Frederico Halbherr, Kreta 